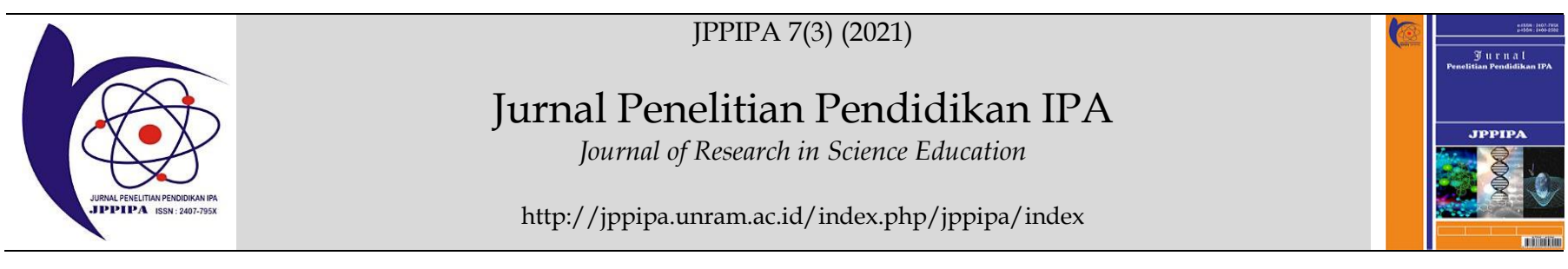

\title{
Magnetic Signatures on River Sediments and Agricultural Soils as Proxy Indicators of Anthropogenic-derived Pollution (Case Study: Cikijing River, Rancaekek, West Java)
}

\author{
Dini Fitriani ${ }^{1,2,3^{*}}$, Widya Utami ${ }^{1}$, Kartika Hajar Kirana ${ }^{1,2,3}$, Eleonora Agustine ${ }^{1,2,3}$, Siti Zulaikah ${ }^{4}$ \\ ${ }^{1}$ Department of Geophysics, Faculty of Mathematics and Natural Sciences, Universitas Padjadjaran, Sumedang, Indonesia. \\ ${ }^{2}$ Center of Citarum Research, Universitas Padjadjaran, Bandung, Indonesia. \\ ${ }^{3}$ Center of Study for Earth Engineering, Science, Natural Resources, Energy and Environment, Universitas Padjadjaran, Sumedang, \\ Indonesia. \\ ${ }^{4}$ Department of Physics, Faculty of Mathematics and Natural Sciences, Universitas Negeri Malang, Malang, Indonesia.
}

DOI:

\section{Article Info}

Received: March 24th, 2021

Revised: June $1^{\text {th }}, 2021$

Accepted: June 23th, 2021

\begin{abstract}
A number of activities occur around the Cikijing River in Rancaekek area, West Java, such as industrial and domestic activities. The various activities could decrease the quality of the river and surrounding environment due to anthropogenic pollutants that might be produced. Since the Cikijing River is also used as the source of irrigation, paddy fields around the river could be also be affected. The presence of pollutants in river sediments and agricultural soils over a long period could change their magnetic properties. Magnetic susceptibility of Cikijing River sediments and soils of the paddy fields in the surrounding have been examined considering that magnetic properties could represent environmental conditions. The results show that river sediments have magnetic susceptibility $\left(\chi_{\mathrm{LF}}\right)$ in range of $356.2-456.3\left(\times 10^{-8}\right) \mathrm{m}^{3} \mathrm{~kg}^{-1}$, whereas soils samples have $\chi_{\mathrm{LF}}$ varying from 94.1 to $347.1\left(\times 10^{-8}\right) \mathrm{m}^{3} \mathrm{~kg}^{-1}$, suggesting domination of ferrimagnetic minerals. The $\chi_{\mathrm{FD}}(\%)$ is $<4 \%$ indicating the anthropogenic origin of magnetic minerals. Electron microscopy images show the imperfect octahedral and spherules shapes of magnetic grains that supports magnetic susceptibility analysis about the source of magnetic minerals. Elemental composition analysis reveals $\mathrm{Fe}$ and $\mathrm{O}$ 's content as main elements, including minor elements of $\mathrm{Ca}, \mathrm{Mg}, \mathrm{Al}$. Si, Ti and $\mathrm{Cr}$.
\end{abstract}

Keywords: magnetic susceptibility, sediments, Cikijing River, anthropogenic

Citation: Fitriani, D., Utami, W., Kirana, K., Agustine, E., \& Zulaikah, S. (2021). Magnetic Signatures on River Sediments and Agricultural Soils as Proxy Indicators of Anthropogenic-derived Pollution (Case Study: Cikijing River, Rancaekek, West Java). Jurnal Penelitian Pendidikan IPA, 7(3), 381-387. doi:https://doi.org/10.29303/ippipa.v7i3.697

\section{Introduction}

The environmental condition may change due to the entry of pollutants derived from natural processes and human activities (anthropogenic sources). The pollutants could be deposited in natural materials such as rocks, soil, sediment, dust, and parts of plants. Industrial activities and residential areas have a significant contribution as anthropogenic sources since the activities produce waste in the form of heavy metals such as mercury $(\mathrm{Hg})$, cadmium $(\mathrm{Cd})$ and lead $(\mathrm{Pb})$. Apart from heavy metals, anthropogenic activities simultaneously produce a significant portion of magnetic minerals. Magnetic minerals enhancement was closely related to environmental processes. The presence of heavy metals and magnetic minerals on various environmental media allows magnetic properties as a proxy indicator of pollution. 
Measurement of magnetic properties has become a generally accepted method for assessing environmental pollution problems and understanding the various processes that occur in different environmental conditions (Mejia-Echeverry et al, 2018) since the measurements are simple, efficient in time, and nondestructive.

Numerous studies have examined the magnetic properties of natural materials and related them with the processes that occur in the environment, inferring that magnetic measurements combined with other analyses are suitable for environmental assessment. Cervi et al (2014) and Lukasik et al (2016) identified magnetic properties of soil and their relation to heavy metal content. In other studies, Bijaksana \& Huliselan (2010), Novala et al, (2016) and Fitriani et al, (2018) described the magnetic properties of leachate from landfills. Magnetic properties of tree leaves (Marié et al, 2016) and tree bark (Brignole et al, 2018) as indicators of air pollution were also characterized.

Industrial and domestic activities have potential as sources of hazardous heavy metals and anthropogenic magnetic materials. The materials could be deposited on the riverbed. As a result, river sediments represent a natural collector of pollutants, providing information on pollution sources contribution. Due to the important roles in human life, such as agricultural irrigation, economic resources, and industrial activities, it is essential to assess river conditions. Chaparro et al (2015) evaluated river conditions through magnetic analysis of river sediments in India, confirming a significant correlation between magnetic properties and heavy metal content. Similarly, in Indonesia, magnetic properties measurements of river sediment have also been carried out in several rivers, such as in Brantas River, East Java (Mariyanto et al, 2019), and Citarum River (Kirana et a., 2014; Sudarningsih et al, 2017). An earlier study reveals the variation of magnetic properties of Citarum River sediments and the correlation with seasons (Fitriani, 2002).

In this work, magnetic properties of river sediments collected from Cikijing River that flows across Rancaekek area in West Java were examined. The research is focused on magnetic susceptibility as a proxy indicator of pollution. Magnetic susceptibility of soils in paddy fields as agricultural soils was also identified. It is necessary to assess the impact of anthropogenic pollutants on paddy fields in surrounding since the river is very important as irrigation resources. Our research was integrated with morphological and mineralogical analyses of magnetic minerals. The analyses were performed by JEOL JSM6510A Scanning Electron Microscopy (SEM) equipped with JED-2300 Energy Dispersive Spectroscopy (EDS)

\section{Method}

Cikijing River and its surrounding as studied area are located in Rancaekek, West Java (6 $6^{\circ} 7^{\prime} 52.06^{\prime \prime}$ E and $\left.107^{\circ} 46^{\prime} 13.15^{\prime \prime} \mathrm{S}\right)$, which is a densely populated area. In addition, there are many industries operated in this area. Cikijing River is a branch of Citarik River. Citarik River is one of sub-watershed of Citarum River as the longest river in West Java. River sediments were collected from upstream to downstream of Cikijing River. There are four sampling points with an interval of $1 \mathrm{~km}$. On the other hand, soil samples from paddy fields were also obtained from four sampling areas. There are three soil samples within each area with a 10 $\mathrm{m}$ interval of sampling points away from the river. Figure 1 displayed the detailed location of sampling points.

In laboratory, the collected samples were cleaned up from macroscopic impurities and dried at room temperature. For magnetic susceptibilities measurements, all samples were then placed in standard cylindrical plastic holders $\left(10 \mathrm{~cm}^{3}\right)$. The measurements were performed using the Bartington Magnetic Susceptibility System with MS2B sensor. The instrument can be operated in dual frequencies to obtain volume-specific magnetic susceptibility at low $(470 \mathrm{~Hz})$ and high frequency $(4700 \mathrm{~Hz})$, namely $\mathrm{K}_{\mathrm{LF}}$ and $\mathrm{K}_{\mathrm{HF}}$, respectively. The calculated mass-specific magnetic susceptibility was obtained using formula $\chi=\kappa / \rho$, which $\rho$ is mass of samples divided by its volume. Frequency-dependent susceptibility or $\chi_{\mathrm{FD}}(\%)$, which indicates the presence of ultrafine superparamagnetic (SP) grains, were computed using formula of $\chi_{\mathrm{FD}}(\%)=$ $100 \% \times\left(\chi_{\mathrm{LF}}-\chi_{\mathrm{HF}}\right) / \chi_{\mathrm{LF}}$.

Two selected dried samples as representative samples of river sediments and soils were extracted using a magnetic stirrer and strong hand magnet to obtain magnetic grains. Furthermore, the extracted magnetic grains were subjected to SEM analysis for providing information about the morphology of magnetic minerals and equipped with EDS to identify and quantify the elemental composition of targeted magnetic grains.

\section{Result and Discussion}

Results from magnetic susceptibility measurement and the calculated parameter of $\chi_{\mathrm{FD}}(\%)$ of river sediments and soils are shown in Table 1 and Table 2, respectively. River sediments have massspecific magnetic susceptibility $\chi_{\mathrm{LF}}$ in the range of 356.2 $-456.3\left(\times 10^{-8}\right) \mathrm{m}^{3} \mathrm{~kg}^{-1}$ with an average of $394.8 \times 10^{-8}$ $\mathrm{m}^{3} \mathrm{~kg}^{-1}$. Compared with other studies, the $\chi_{\mathrm{LF}}$ of sediments from Cikijing River has lower values than 
river sediments originating from Brantas River (Mariyanto et al, 2019) and Citarum River, starting from Balekambang to Nanjung (Sudarningsih et al, 2017) as reported. Meanwhile, soils from paddy fields have $\chi_{\mathrm{LF}}$ lower than those of river sediments in the range of $128.3-374.1(\times 10-8) \mathrm{m}^{3} \mathrm{~kg}^{-1}$ (on average of $\left.211.6 \times 10^{-8} \mathrm{~m}^{3} \mathrm{~kg}^{-1}\right)$. In general, magnetic susceptibility corresponds to the content of ferrimagnetic minerals. Samples with $\chi_{\mathrm{LF}}$ higher than $10 \times 10^{-8} \mathrm{~m}^{3} \mathrm{~kg}^{-1}$ are controlled by ferrimagnetic minerals (Dearing, 1999). According to this criterion, it infers the domination of ferrimagnetic minerals in all samples.

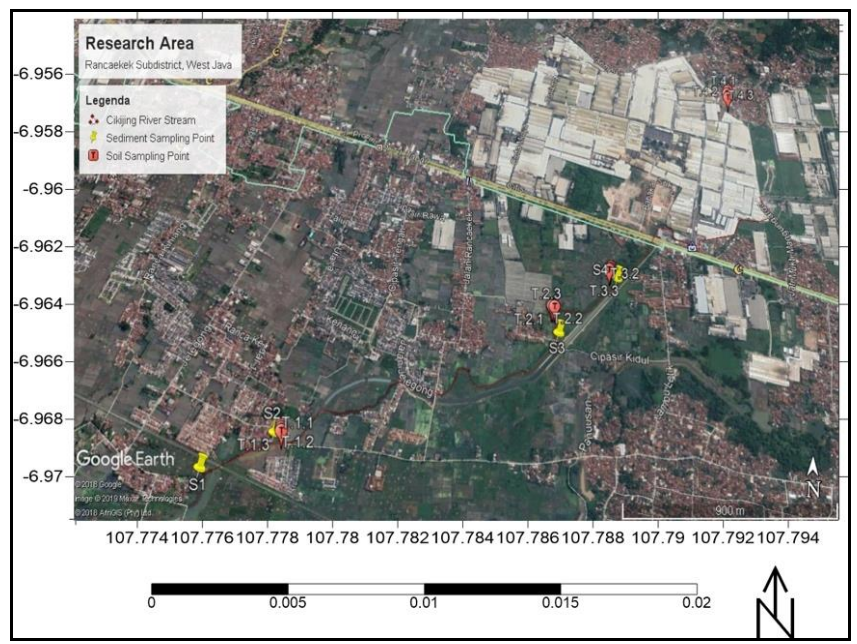

Figure 1. Sampling locations in the area under investigation. River sediments were collected along Cikijing River from four different stations, denoted by yellow pins. Agricultural soils were obtained from four sampling areas (red pins).

Magnetic susceptibilities of river sediments tend to fluctuate from upstream to downstream. Higher magnetic susceptibilities were found for samples from downstream (S1 and S2) than samples from upstream (S3 and S4). It indicates the spatial differences of river sediments of both areas based on magnetic susceptibility values. The downstream sampling points were in densely populated residential areas suggesting the contribution of magnetic minerals from domestic wastes.

Soil samples from paddy fields have magnetic susceptibility values lower than those of river sediments. The $\chi_{\mathrm{LF}}$ of soil samples tends to increase from upstream (T1) to downstream (T4), as shown in Figure 2. The highest value was obtained for the soil sample from the sampling point of T4. It is possibly due to the sampling point is close to industrial areas. The $\chi_{\mathrm{LF}}$ values were relatively higher than those reported in research for other paddy fields (Fitriani et al, 2016). For the sample obtained from T2 sampling point, the trend of $\chi_{\mathrm{LF}}$ is characterized by declining values with lateral distance away from the river. Soil samples taken adjacent to river bank have magnetic susceptibilities higher than samples far from river bank. Meanwhile, other soil samples tend to have fluctuated magnetic susceptibilities values.

Table 1: Magnetic susceptibility $\left(\chi_{\mathrm{LF}}\right.$ and $\left.\chi_{\mathrm{HF}}\right)$ and frequency-dependent susceptibility $\left(\chi_{\mathrm{FD}}(\%)\right)$ of river sediments.

\begin{tabular}{lllll}
\hline No & Samples & $\begin{array}{l}\chi_{\mathrm{LF}} \\
\left(\times 10^{-8} \mathrm{~m}^{3} / \mathrm{kg}\right)\end{array}$ & $\begin{array}{l}\chi_{\mathrm{HF}} \\
\left(\times 10^{-8} \mathrm{~m}^{3} / \mathrm{kg}\right)\end{array}$ & $\chi_{\mathrm{FD}}(\%)$ \\
\hline 1 & S1 & 401.9 & 391.9 & 2.49 \\
2 & $\mathrm{~S} 2$ & 456.3 & 447.1 & 2.01 \\
3 & $\mathrm{~S} 3$ & 356.2 & 345.0 & 3.15 \\
4 & $\mathrm{~S} 4$ & 364.9 & 359.6 & 1.47 \\
\hline
\end{tabular}

Table 2: The value of $\chi_{\mathrm{LF}}, \chi_{\mathrm{HF}}$ and $\chi_{\mathrm{FD}}(\%)$ of soils taken from paddy fields.

\begin{tabular}{lllll}
\hline No & Samples & $\begin{array}{l}\chi_{\mathrm{LF}} \\
\left(\times 10^{-8} \mathrm{~m}^{3} / \mathrm{kg}\right)\end{array}$ & $\begin{array}{l}\chi_{\mathrm{HF}} \\
\left(\times 10^{-8} \mathrm{~m}^{3} / \mathrm{kg}\right)\end{array}$ & $\chi_{\mathrm{FD}}(\%)$ \\
\hline 1 & T1-1 & 128.3 & 126.4 & 1.53 \\
2 & $\mathrm{~T} 1-2$ & 212.1 & 211.0 & 0.54 \\
3 & $\mathrm{~T} 1-3$ & 157.3 & 156.7 & 0.38 \\
4 & $\mathrm{~T} 2-1$ & 186.4 & 186.9 & 0.27 \\
5 & $\mathrm{~T} 2-2$ & 176.6 & 175.7 & 0.51 \\
6 & $\mathrm{~T} 2-3$ & 141.7 & 140.0 & 1.21 \\
7 & $\mathrm{~T} 3-1$ & 233.2 & 228.0 & 2.28 \\
8 & $\mathrm{~T} 3-2$ & 214.8 & 207.9 & 3.22 \\
9 & $\mathrm{~T} 3-3$ & 240.7 & 232.4 & 3.45 \\
10 & $\mathrm{~T} 4-1$ & 294.7 & 290.2 & 1.52 \\
11 & $\mathrm{~T} 4-2$ & 374.1 & 369.8 & 1.16 \\
12 & $\mathrm{~T} 4-3$ & 179.4 & 178.6 & 0.47 \\
\hline
\end{tabular}

In addition to industrial and domestic origin, it is necessary to consider the anthropogenic source from other chemical materials. In agricultural activities, agrochemical materials such as pesticides and fertilizer are often used to increase agricultural production. However, a long-term use of the chemicals may cause soil degradation since they may contain heavy metals and magnetic minerals. According to this, it can be inferred the use of agricultural chemical in paddy fields as an additional anthropogenic pollution source.

Table 1 and Table 2 also show the variation of calculated $\chi_{\mathrm{FD}}(\%)$. River sediments have $\chi_{\mathrm{FD}}(\%)$ that vary from $1.47 \%$ to $3.15 \%$, while soil samples vary from $0.27 \%$ to $3.45 \%$. The mean $\chi_{\mathrm{FD}}(\%)$ is $2.28 \%$ for river sediments and $1.38 \%$ for soils. Samples with $\chi_{\mathrm{FD}}(\%)$ less than $2 \%$ are categorized as low $\chi_{\mathrm{FD}}(\%)$, indicating the absence of SP grains (Dearing, 1999). Meanwhile, medium $\chi_{\mathrm{FD}}(\%)$ has the values in the range of $2-10 \%$ that contain the mixture of superparamagnetic and coarser non-superparamagnetic grains. According to this criterion, river sediments have medium $\chi_{\mathrm{FD}}(\%)$ since the values are higher than 2\% (except for S4 sample). 


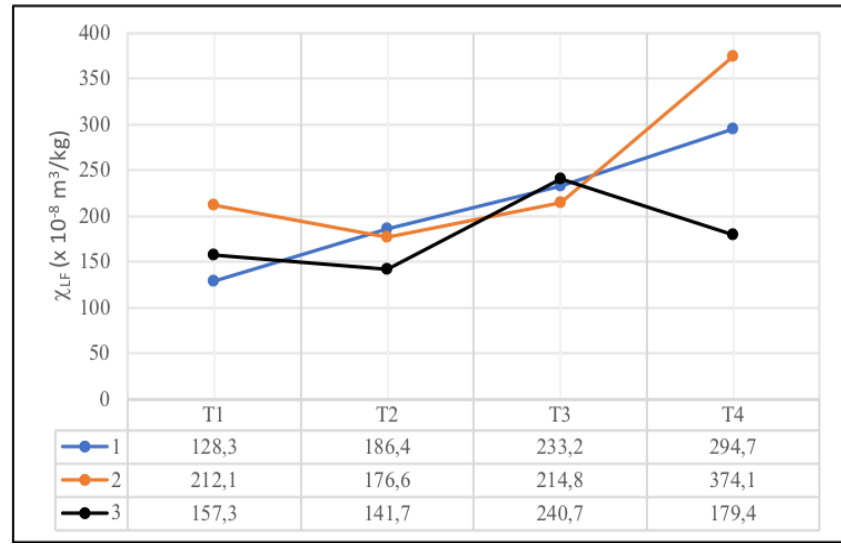

Figure 2. Magnetic susceptibility of soil samples from four paddy fields shows fluctuating values.

Anthropogenic magnetic minerals fall within multidomain stage (Solomon et al, 2017) and show frequency-independent or low $\chi_{\mathrm{FD}}(\%)$. On the other hand, natural magnetic minerals are mostly superparamagnetic. In majority of soil samples have $\chi_{\mathrm{FD}}(\%)$ below $2 \%$, suggesting the anthropogenic origin of magnetic minerals. Another study revealed that the $\chi_{\mathrm{FD}}(\%)$ value in the range of $1-4 \%$ is often found in contaminated soils (Bijaksana \& Huliselan, 2010). Generally, all samples have $\chi_{\mathrm{FD}}(\%)$ less than $4 \%$. The result supported previous analysis concerning the contribution of anthropogenic-derived magnetic minerals in studied samples. Figure 3 shows a plot of $\chi_{\mathrm{FD}}(\%)$ as a function of $\chi_{\mathrm{LF}}$ in order to identify the sources of magnetic minerals and the domain state as modeled in literature (Dearing, 1999). It can be observed that the data points of river sediments and soils tend to cluster at acid igneous and stable single domain (SSD)/MD.

SEM and EDS analyses were carried out on extracted magnetic grains from S2 and T3-1 as representative samples of river sediments and agricultural soils, respectively. SEM images provide morphology and texture of magnetic grains. In both samples, SEM observations showed the presence of octahedral and spherical magnetic grains (Figure 2 and Figure 3). The different shapes of magnetic grains inferred that the grains were derived from different sources. The octahedral shape of grains suggests their pedogenic origin. Magnetic grains with spherical shapes are generally derived from anthropogenic sources (Huliselan et al, 2010). In sample S2, the octahedral shape of magnetic grain was observed, indicating the presence of pedogenic magnetic minerals (Figure 4a). Nevertheless, the grain has imperfect shape and a rough surface, probably due to the influence of anthropogenic sources. As shown in figure $4 b$, there are two spherical grains with a diameter of $\sim 20 \mu \mathrm{m}$. Grain
1 , as denoted in the figure, has a roughly spherical shape.

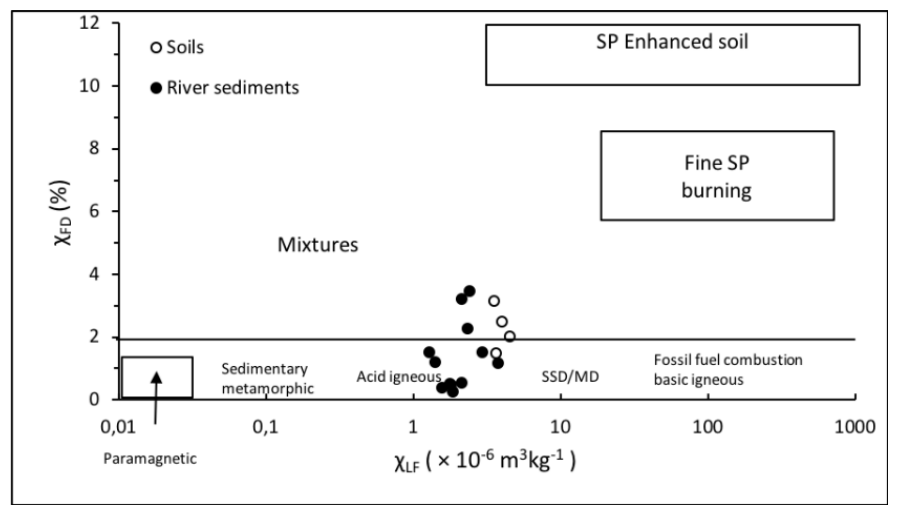

Figure 3. A scattergram of $\chi_{\mathrm{LF}}-\chi_{\mathrm{FD}}(\%)$ for river sediments (solid circles) and soils (hollow circles). The data points tend to cluster at acid igneous and SSD/MD region.
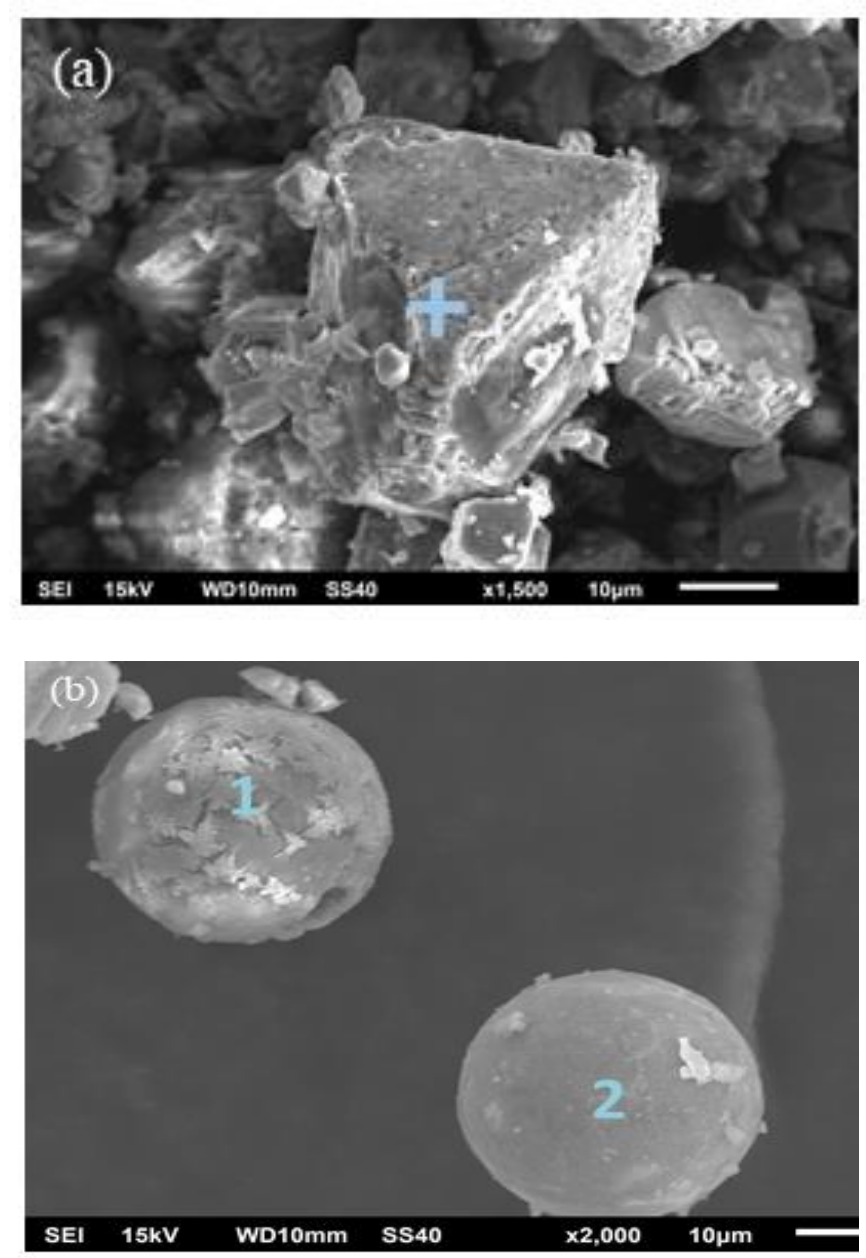

Figure 4. Scanning Electron Microscopy images of extracted grains from S2 showing typical morphology of (a) octahedral shape and (b) spherules shape.

Magnetic grain from T3-1 sample showed an octahedral shape of magnetic grain with a fractured edge (Figure 5a), inferring the grain was pedogenic in 
origin. In addition, Figure $5 \mathrm{~b}$ showed typical magnetic grain derived from anthropogenic sources. The grain has a spherule shape with a pattern on the surface. The grain diameter is $\sim 10-15 \mu \mathrm{m}$, which is smaller than spherule grains in $\mathrm{S} 2$.
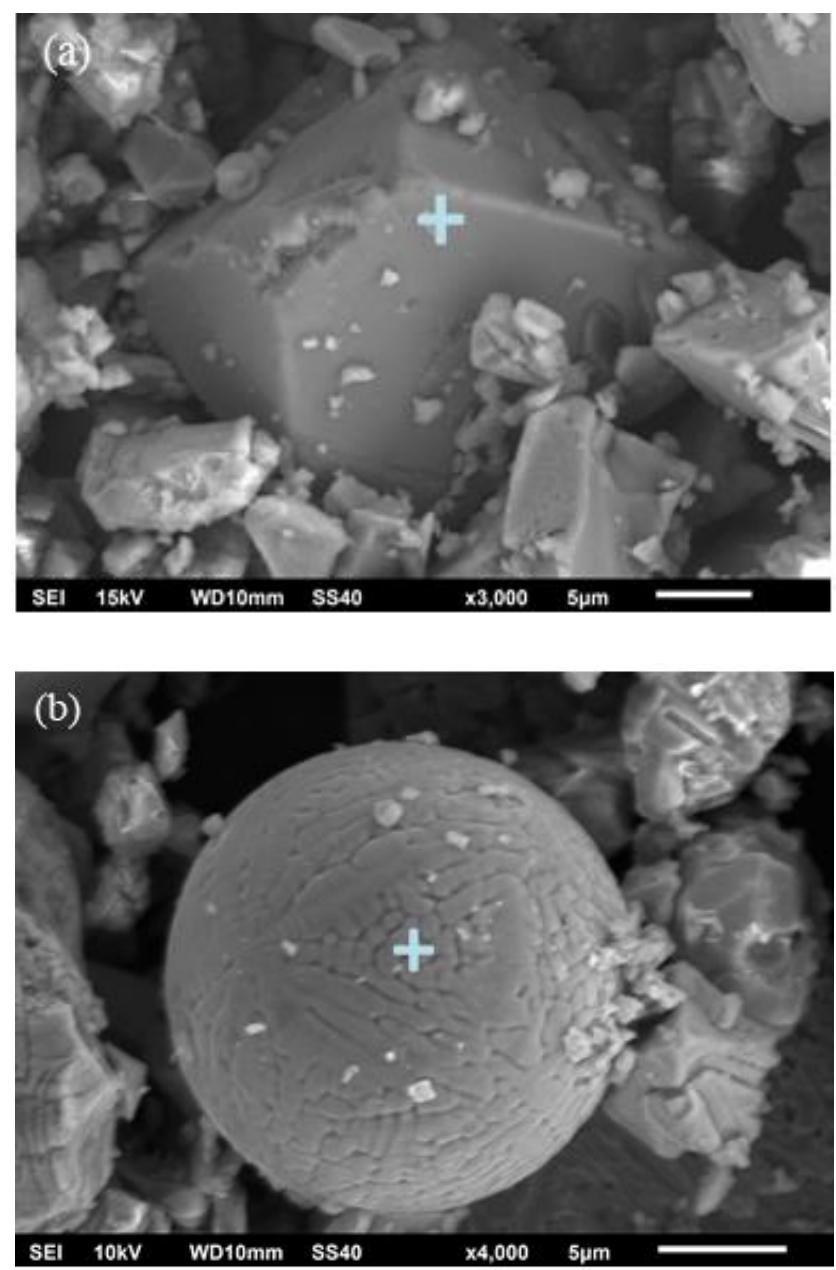

Figure 5. Morphologies of extracted grains from T3-1. The grain in (a) has an octahedral shape with a fractured edge. The grain in (b) shows a spherule shape with a pattern in the surface.

The analysis of elemental composition in the grains of S2 and T3-1 was given in Table 3. EDS analysis of selected grains showed that $\mathrm{Fe}$ and $\mathrm{O}$ as the main elements. The high content of elements Fe and $\mathrm{O}$ in the grains suggests that the grains are iron-oxides. The iron-oxides spherules magnetic grains are usually found in samples from industrial areas. There were also found a number of minor elements with varying concentrations, including $\mathrm{Ca}, \mathrm{Mg}, \mathrm{Al}, \mathrm{Si}, \mathrm{Ti}$, and $\mathrm{Cr}$. Compared to other grains, the concentration of $\mathrm{Si}$ in spherule grains of S2 is much higher. The SEM-EDS results confirmed the contribution of anthropogenic magnetic minerals as obtained from magnetic susceptibility analysis.
Table 3: Elemental composition of extracted magnetic grains from S2 and T3-1 samples according to EDS analysis.

\begin{tabular}{|c|c|c|c|c|c|c|}
\hline \multirow[b]{2}{*}{ No } & \multirow[b]{2}{*}{$\begin{array}{l}\text { Ele- } \\
\text { ments }\end{array}$} & \multicolumn{3}{|c|}{ Mass \% (S2) } & \multicolumn{2}{|c|}{ Mass \% (T3-1) } \\
\hline & & $\begin{array}{l}\text { Octa- } \\
\text { hedral }\end{array}$ & $\begin{array}{l}\text { Sphe- } \\
\text { rule } 1\end{array}$ & $\begin{array}{l}\text { Sphe- } \\
\text { rule 2 }\end{array}$ & $\begin{array}{l}\text { Octa- } \\
\text { hedral }\end{array}$ & $\begin{array}{l}\text { Sphe- } \\
\text { rule }\end{array}$ \\
\hline 1 & $\mathrm{O}$ & 44.84 & 44.94 & 48.42 & 2.53 & 41.76 \\
\hline 2 & $\mathrm{Mg}$ & 1.49 & 2.37 & 2.21 & 0.05 & 0.04 \\
\hline 3 & $\mathrm{Al}$ & 2.23 & 9.49 & 9.39 & 0.48 & 0.18 \\
\hline 4 & $\mathrm{Si}$ & 1.49 & 16.76 & 14.44 & 0.25 & 0.11 \\
\hline 5 & $\mathrm{Ca}$ & 0.09 & 3.75 & 4.04 & 0.08 & 0.03 \\
\hline 6 & $\mathrm{Ti}$ & 10.05 & 0.39 & 0.26 & 9.79 & 0.49 \\
\hline 7 & $\mathrm{Cr}$ & 0.13 & - & 0.09 & 0.07 & - \\
\hline 8 & $\mathrm{Fe}$ & 38.41 & 16.71 & 19.03 & 85.29 & 55.86 \\
\hline 9 & $\mathrm{Ni}$ & - & - & 0.12 & - & 0.32 \\
\hline 10 & $\mathrm{Cu}$ & 0.45 & 0.81 & 0.57 & 0.84 & 0.88 \\
\hline 11 & $\mathrm{Zn}$ & 0.52 & 0.53 & 0.91 & 0.14 & 0.01 \\
\hline 12 & As & - & - & - & - & 0.09 \\
\hline 13 & $\mathrm{Cd}$ & 0.19 & 0.09 & 0.37 & 0.19 & 0.22 \\
\hline 14 & $\mathrm{Hg}$ & - & 0.14 & 0.15 & 0.06 & - \\
\hline 15 & $\mathrm{~Pb}$ & 0.01 & - & - & 0.23 & - \\
\hline \multicolumn{2}{|c|}{ Total } & 100 & 100 & 100 & 100 & 100 \\
\hline
\end{tabular}

\section{Conclusion}

According to magnetic susceptibility values, river sediments from Cikijing River and soils from surrounding paddy fields are dominated by ferrimagnetic minerals. Analysis based on $\mathrm{X}_{\mathrm{FD}}(\%)$ values infer that mostly magnetic minerals originate from anthropogenic sources with multidomain state. Scattergram of $\chi_{\mathrm{LF}}-\chi_{\mathrm{FD}}(\%)$ also shows the multidomain state of magnetic minerals. SEM observation identified that magnetic minerals have imperfect octahedral and spherules in shapes, suggesting their natural and anthropogenic origins. SEM analysis supports findings from magnetic susceptibility measurements about the sources of magnetic minerals. Elemental composition from EDS analysis reveals the high content of $\mathrm{Fe}$ and $\mathrm{O}$, suggesting the iron-oxides minerals. Numbers of minor elements with varying concentrations were also found. The availability of elements as nutrients in soils, such as $\mathrm{Ca}, \mathrm{Mg}, \mathrm{Cu}, \mathrm{Zn}$ and $\mathrm{Fe}$, are needed for soil fertility and plant growth. In order to determine suitable plants in agricultural soils, further research is needed on the physical properties of the soil as well as chemical properties. Magnetic properties of natural materials, such as sediments and soils, could be useful parameters as proxy indicators of environmental processes, including pollution records.

\section{Acknowledgements}

The authors would like to thank Department of Geophysics, FMIPA Universitas Padjadjaran for the support during the research. 


\section{References}

Bijaksana, S., \& Huliselan, E. K. (2010). Magnetic properties and heavy metal content of sanitary leachate sludge in two landfill sites near Bandung, Indonesia. Environmental Earth Sciences, 60(2), 409-419. doi: https://doi.org/10.1007/s12665-009-0184-4.

Brignole, D., Drava, G., Minganti, V., Giordani, P., Samson, R., Vieira, J., Pinho, P., \& Branquinho, C. (2018). Chemical and magnetic analyses on tree bark as an effective tool for biomonitoring: A case study in Lisbon (Portugal). Chemosphere, 195, 508-514.

doi: https://doi.org/https://doi.org/10.1016/i.chem osphere.2017.12.107

Cervi, E. C., da Costa, A. C. S., \& de Souza Junior, I. G. (2014). Magnetic susceptibility and the spatial variability of heavy metals in soils developed on basalt. Journal of Applied Geophysics, 111, 377-383. https://doi.org/https://doi.org/10.1016/j.jappg eo.2014.10.024.

Chaparro, M. A. E., Krishnamoorthy, N., Chaparro, M. A. E., Lecomte, K. L., Mullainathan, S., Mehra, R., \& Sinito, A. M. (2015). Magnetic, chemical and radionuclide studies of river sediments and their variation with different physiographic regions of Bharathapuzha river, southwestern India. Studia Geophysica et Geodaetica, 59(3), 438-460. https://doi.org/10.1007/s11200-014-0145-6.

Dearing, J.A. (1999). Environmental Magnetic Susceptibility: using the Bartington MS2 System $2^{\text {nd }}$ ed. Chi Pub. Kenilworth pp. 1-54

Fitriani, D., Kirana, K.H, Agustine, E., Hasanah, M.U., \& Susilawati, A. (2018). Magnetic susceptibility, morphological and magnetic mineral composition analysis on leachate sludge. Proceedings of International SEGJ Symposium. 452455. https://doi.org/10.1190/SEGJ2018-116.1

Fitriani, D., Darmasetiawan, R., Harja, A., \& Agustine, A. (2016). Magnetism and morphology of magnetic minerals from agricultural soils: A proxy indicator of pollution, Proc. Geological and Earth Sciences, $15-18$. https://doi.org/10.5176/2251-3353_GEOS16.10

Fitriani, D. (2002). Variasi parameter magnetik dan sedimen sungai pada musim hujan dan musim kemarau. (Unpublished master thesis). Institut Teknologi Bandung, Indonesia. [Indonesian]

Huliselan, E. K., Bijaksana, S., Srigutomo, W., \& Kardena, E. (2010). Scanning electron microscopy and magnetic characterization of iron oxides in solid waste landfill leachate. Journal of Hazardous Materials, 179(1), 701-708. https://doi.org/https://doi.org/10.1016/j.jhaz mat.2010.03.058.

Kirana, K.H., Fitriani, D., Supriyana, E., \& Agustine, E. (2014). Sifat magnetik sedimen sungai sebagai indicator pencemaran (Studi kasus: Sungai Citarum, Kabupaten Karawang), Jurnal SpektraI, 15 (2), 40-42. [Indonesian]

Łukasik, A., Magiera, T., Lasota, J., \& Błońska, E. (2016). Background value of magnetic susceptibility in forest topsoil: Assessment on the basis of studies conducted in forest preserves of Poland. Geoderma, 264, 140-149. https://doi.org/https://doi.org/10.1016/j.geod erma.2015.10.009.

Marié, D. C., Chaparro, M. A. E., Irurzun, M. A., Lavornia, J. M., Marinelli, C., Cepeda, R., Böhnel, H. N., Castañeda Miranda, A. G., \& Sinito, A. M. (2016). Magnetic mapping of air pollution in Tandil city (Argentina) using the lichen Parmotrema pilosum as biomonitor. Atmospheric Pollution Research, 7(3), 513-520. https://doi.org/https://doi.org/10.1016/j.apr.2 $\underline{015.12 .005}$.

Mariyanto, M., Amir, M. F., Utama, W., Hamdan, A. M., Bijaksana, S., Pratama, A., Yunginger, R., \& Sudarningsih, S. (2019). Heavy metal contents and magnetic properties of surface sediments in volcanic and tropical environment from Brantas River, Jawa Timur Province, Indonesia. Science of The Total Environment, 675, 632-641. https://doi.org/https://doi.org/10.1016/j.scitot env.2019.04.244.

Mejia-Echeverry, D., Chaparro, M., Duque-Trujillo, J. F., \& Restrepo, J. D. (2018). An environmental magnetism approach to assess impacts of landderived sediment disturbances on coral reef ecosystems (Cartagena, Colombia). Marine pollution bulletin, $131(\mathrm{Pt} \quad \mathrm{A}), \quad 441-452$. https://doi.org/10.1016/j.marpolbul.2018.04.03.

Novala, G. C., Fitriani, D., Susanto, K., \& Kirana, K. H. (2016). Magnetic Properties of Soils from Sarimukti Landfill as Proxy Indicators of Pollution (Case Study: Desa Sarimukti, Kabupaten Bandung Barat). IOP Conference Series: Earth and Environmental Science, 29, 12015. https://doi.org/10.1088/17551315/29/1/012015.

Solomon, J.S., Ahmed, A.L, Adamu, I.H., \& Dimu, O.O. (2017). Identifying anthropogenic metallic pollutants using frequency dependent magnetic susceptibility measurements in Abuja Metropolis. Current Trends in Natural Sciences, 6 (11), 13-22.

Sudarningsih, S., Bijaksana, S., Ramdani, R., Hafidz, A., Pratama, A., Widodo, W., Iskandar, I., Dahrin, D., 
Jannatul Fajar, S., \& Agus Santoso, N. (2017).

Variations in the Concentration of Magnetic Minerals and Heavy Metals in Suspended Sediments from Citarum River and Its Tributaries, West Java, Indonesia. In Geosciences. 7(3). https://doi.org/10.3390/geosciences7030066. 